\title{
Analysis of Science Process Skills in Senior High School Students
}

\author{
Ardina Dwiyani Inayah, Rizhal Hendi Ristanto*, Diana Vivanti Sigit, Mieke Miarsyah \\ Department of Biology Education, Faculty of Mathematics and Natural Science, Universitas Negeri Jakarta, Indonesia
}

Received October 19, 2019; Revised January 27, 2020; Accepted March 24, 2020

Copyright $\bigcirc 2020$ by authors, all rights reserved. Authors agree that this article remains permanently open access under the terms of the Creative Commons Attribution License 4.0 International License

\begin{abstract}
Science process skill is one of the important skills possessed by students in studying Biology. That is because the process of learning Biology cannot be separated from scientific processes, such as observing, experimenting, and analyzing activities. Good science process skills are believed to be able to help students understand Biology concepts easily and correctly. The purpose of this study was to analyze the science process skills possessed by high school students in Cilegon city. This research was conducted in February 2019, the sample was taken using the simple random sampling method with a total sample of 35 students. The research used descriptive quantitative method. Data was collected by the science process skills test instrument. The results show that the average score of science process skills possessed by students is still categorized as sufficient, because the average value of science process skills obtained from 35 students were 58 .
\end{abstract}

Keywords Science Process Skill, Biology, Scientific Process Science Process Skill, Biology, Scientific Process

\section{Introduction}

Biology is a science that cannot be separated from scientific activities. Biology is closely related to activities in finding out and understanding nature in a systematic way, so that learning not only requires knowledge in the form of facts, concepts, and or principles but also requires a scientific process [1]. In carrying out the process of scientific activities of course, a skill is needed.
Science process skill is one of the important skills possessed by students in conducting scientific activities. Scientific activities are closely related to the Biology learning process, because Biology learning cannot be separated from the scientific process, such as observing, experimenting, and analyzing activities. Science process skills are believed to be able to improve scientific literacy [2], help students understand Biology concepts easily and correctly. During the learning process, students are required to be active in discovering the main concepts of Biology material through observation, experimentation, drawing pictures, graphs, tables, and communicating the results to others [3].

Science Process Skills are classified into two kinds. There are basic science process skill and integrated science process skill [4]. That is shown in table 1.

Science process skills help students to develop a sense of responsibility in learning and increase how important research methods are in the learning process [5]. Science process skills are useful for students to be more active in understanding a concept [6,7]. Science process skills are also not only useful in the learning process in the classroom, but also useful in solving problems in everyday life. Individuals who cannot have good scientific process skills will experience difficulties in daily life, because these skills are not only used during education, but are also used in everyday life [8-10].

Based on this, it can be seen how important science process skills are in daily life, especially when conducting learning activities. Therefore, it is necessary to conduct research on the analysis of science process skills in high school students. 
Table 1. Classification of Science Process Skill

\begin{tabular}{|c|c|c|}
\hline \multirow{4}{*}{$\begin{array}{c}\text { Basic Science } \\
\text { Process Skill }\end{array}$} & Observing & Paying attention to the properties of objects and events using the five senses. \\
\cline { 2 - 3 } & Interpreting & Expressing the number of objects or substances quantitatively. \\
\cline { 2 - 3 } & Classifying & Provide an explanation for a particular object or substance quantitatively. \\
\cline { 2 - 3 } & Predicting & Connecting objects and events according to their nature or characteristics. \\
\hline \multirow{4}{*}{$\begin{array}{c}\text { Integrated } \\
\text { Science Process } \\
\text { Skill }\end{array}$} & Communicating & Forecasting future events based on past observations or data extensions. \\
\cline { 2 - 3 } & Controlling Variables & $\begin{array}{c}\text { Manipulating and controlling properties related to the situation of events for the } \\
\text { purpose of determining cause and effect. }\end{array}$ \\
\cline { 2 - 3 } & Making a Hypothesis & $\begin{array}{c}\text { Stating tentative generalizations from observations or conclusions that can be used } \\
\text { to explain a relatively larger number of events but they must be tested with an } \\
\text { experiment or more. }\end{array}$ \\
\cline { 2 - 3 } & Conducting Experiments & $\begin{array}{c}\text { Testing hypotheses through the manipulation and control of independent variables } \\
\text { and observing the influence on the dependent variable: interpreting and presenting } \\
\text { results in the form of reports that can be followed by others to experiment. }\end{array}$ \\
\hline Interpreting Data & $\begin{array}{c}\text { Results of explanations, conclusions, or hypotheses from data that have been } \\
\text { graphed or placed in tables. }\end{array}$ \\
\hline
\end{tabular}

\section{Materials and Methods}

This study used quantitative descriptive research with ex post facto research method. This study aims to measure and analyze science process skills in students. The target population in this study were all students at SMAN 2 Krakatau Steel Cilegon, while the affordable population was all students of class XII MIA at SMA N 2 Krakatau Steel Cilegon. The research sample was selected using purposive sampling technique. Then a sample of 35 students was obtained in class XII MIA academic year 2018/2019.

The instrument used in this study was a science process skill test that was developed based on Chiapetta and Koballa's science process skill indicators. The instrument consists of 20 questions in the form of multiple choices that had been tested for validity. Then the valid instrument was distributed to senior high school students to measure their science process skills score. The score was interpreted by using Arikunto's score interpretation criteria [11]. Then the results were obtained, analyzed using descriptive statistical analysis. (Table 2).

Table 2. Score Interpretation Criteria by Arikunto

\begin{tabular}{|c|c|}
\hline Score Range & Criteria \\
\hline $0-20$ & Very Bad \\
\hline $21-40$ & Bad \\
\hline $41-60$ & Sufficient \\
\hline $61-80$ & Good \\
\hline $81-100$ & Very Good \\
\hline
\end{tabular}




\section{Results and Discussion}

\section{a. Science process skills of students}

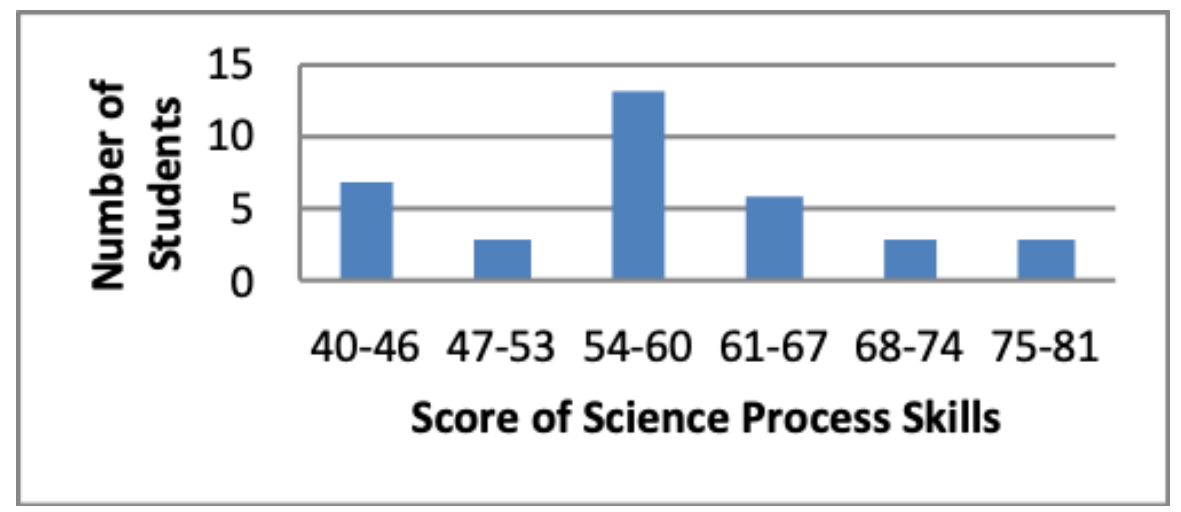

Figure 1. Graph of Science Process Skill Average Score

In the score regarding the science process skills, it is obtained that the lowest score is 40 and the highest score is 80 with an average score of 58. The highest frequency is in the range of scores of 54-60, as many as 13 people and at least there is in the range of scores $47-53 ; 68-74 ; 75-81$, each consisting of 3 people. Based on the score interpretation criteria [11], the majority of class X MIA students in SMA N 2 Krakatau Steel Cilegon city have sufficient science process skills.

These are the examples of question about science process skill test for each dimension(That is shown in table 3.):

Table 3. Science Process Skills Test

\begin{tabular}{|c|c|c|c|}
\hline $\begin{array}{l}\text { Dimension of Science } \\
\text { Process Skill }\end{array}$ & \multicolumn{3}{|c|}{ Question } \\
\hline Observing & \multicolumn{3}{|c|}{$\begin{array}{l}\text { The activity of seeing similarities and differences through observations about the parenchyma } \\
\text { tissue with the tissue collenchyma tissue in plants, is an example of ? }\end{array}$} \\
\hline Measuring & \multicolumn{3}{|c|}{$\begin{array}{l}\text { A group of students conducts experiments to determine the effect of light intensity on the } \\
\text { growth of grass height. What skills must they have in conducting the experiment? }\end{array}$} \\
\hline \multirow{5}{*}{ Interpreting } & \multicolumn{3}{|c|}{ Based on the table of trial results below, what can you conclude } \\
\hline & No. & Condition & $\Sigma$ Pulse / minutes \\
\hline & 1. & Sitting down & $75 \mathrm{x} /$ minutes \\
\hline & 2. & After walk $100 \mathrm{~m}$ & $86 x /$ minutes \\
\hline & 3. & After up down stairs $2 \mathrm{x}$ & $98 \mathrm{x} /$ minutes \\
\hline
\end{tabular}




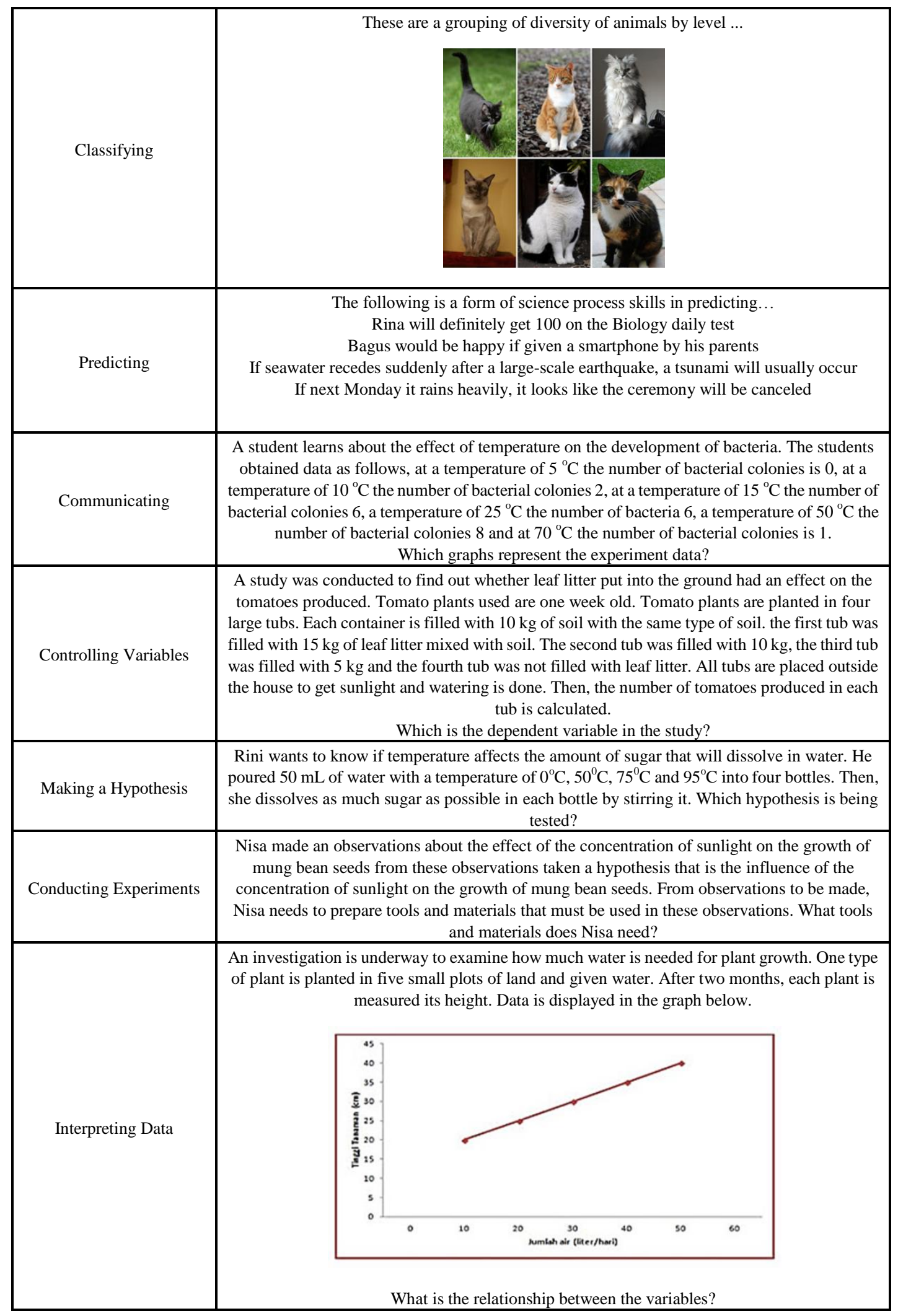




\section{b. Indicator of science process skills}

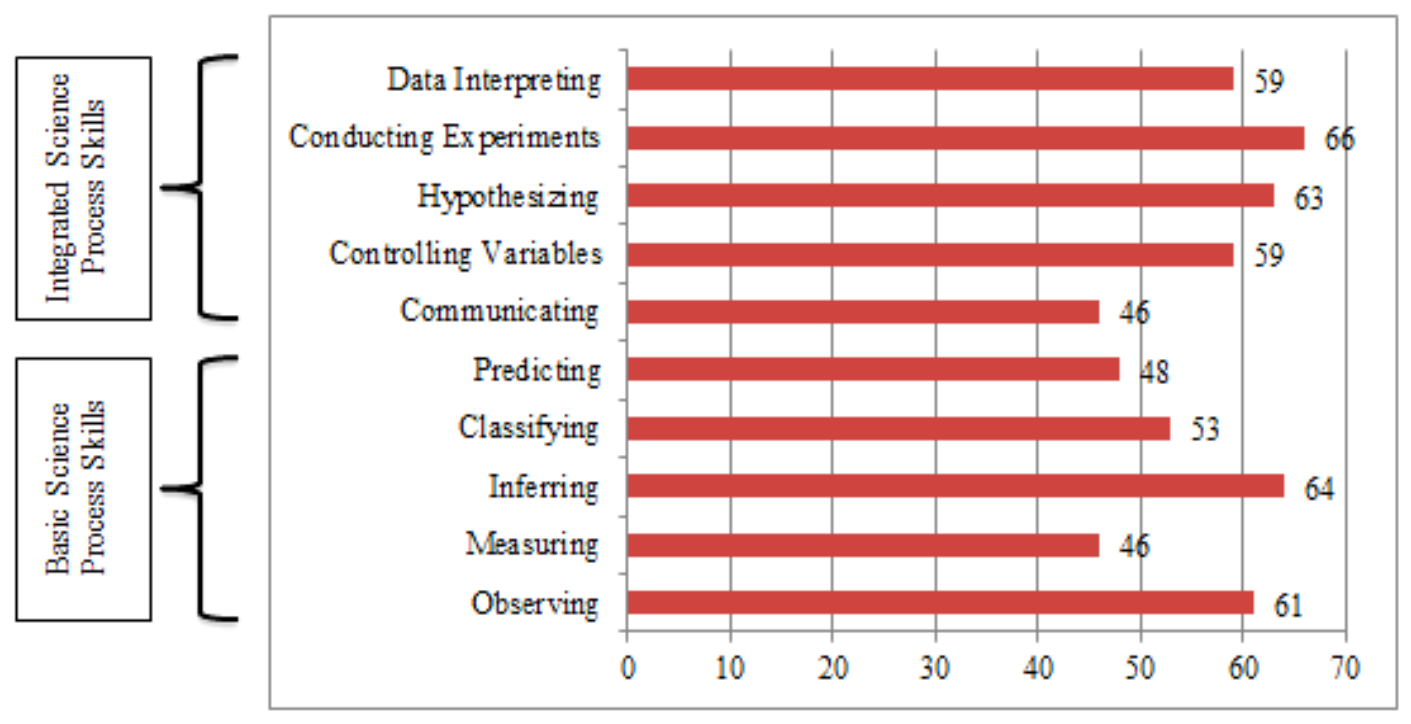

Figure 2. Graph of Average Scores for Each Science Process Skill Indicator

In the average score for each indicators of science process skills possessed by students, it showed that the highest science process skills were in the skill of conducting experiments whose score was 66, which is based on the score interpretation criteria by Arikunto categorized as good, whilst the lowest score of science process skills were in measure skill and communication skills, each of dimension score was 46 , which is based on the score interpretation criteria by Arikunto categorized as bad.

The average score of observing skills that possesed by students was only 61. Based on the score interpretation criteria by Arikunto, it is categorized as good. The observing skill is the most basic process in learning science and very important to upgrading the other science process skills, such as measuring skills, inferring skills, classification skills, and communication skills [12]. This was one of the reasons why the other average score for each indicator of science process skills was categorized only as sufficient.

The average score of concluding skills possessed by students was 64. Based on the score criteria interpretation by Arikunto, it is categorized as good. The inferring skill is an ability to decide the state of an object or event based on the desired facts, concepts, and principles [13]. To practice the ability of students about inferring, students need a learning model that has a philosophy of constructivism, that makes students active because it requires students to build their own knowledge. One learning model which has a philosophy of constructivism is the discovery learning model. Discovery learning can help students to improve their basic science process skills [14]. Discovery learning model is learning by using the discovery process so that students can find or re-prove a concept in the form of definitions or conclusions [15].

The average score of classifying skills that possessed by students was 53. Based on the score criteria interpretation by Arikunto, it is categorized as enough. This is probably due to the teaching, especially the material on classification, which is only taught through lecture and discussion methods. For example, when students learn about the classification of living things, students learn the types of classifications that have been made, so learning is less meaningful and does not encourage students to think actively. Students are introduced too early to a ready-made classification system about grouping living things, so students do not form their own classification concepts but rather imitate the existing systems [7]. Classifying is a process skill to sort out various objects of events based on their specific characteristics, so that there are groups / groups of similar types in question [13]. Classifying skills can develop the ability of students to think logically and flexibly. Therefore the ability of classification is very important to be developed at various levels of education, being primary, secondary, or at a higher level [7]. Such as using EL learning model, it can give the opportunity to the students to do the learning activities actively. It will guide them to get more experiences through their active involvement rather than reading the materials or concepts [16].

The average score of predicting skills that possessed by students was 48. Based on the score criteria interpretation by Arikunto, it is categorized as bad. Predicting skill is ability to anticipate or make predictions about everything that will happen in the future, based upon a pattern of evidence [13]. The ability to make predictions about future 
events allows us to successfully interact with the environment around us [17].

The students predicting skills were bad, maybe it was caused by the learning process that does not exercise students to build skill of predicting. Teachers can help students to develop predicting skills by making connections between predicting while reading and predicting in science. Students will not necessarily make these connections independently, so teacher talk and questioning are important.

The average score of controlling variables skills that possessed by students was 59. Based on the score interpretation criteria by Arikunto, it is categorized as sufficient. Controlling variables skill is ability to state the factors or variables which affect the experiment. It is important to manipulate the variables being tested and keep all other variable constant. The one being manipulated is the independent variable. The one being measured is the dependent variable.

The average score of hypothesizing skills that possessed by students was 63 . Based on the score interpretation criteria by Arikunto, it is categorized as good. The hypothesizing skill is ability to formulate the tentative statements or expected outcome for experiments. These statements must be testable.

The average score of data interpreting skills that possessed by students was 59. Based on the score interpretation criteria by Arikunto, it is categorized as sufficient. The data interpreting skill is being able to connect the results of observation with the object to draw conclusions [13].

The average score of conducting experiment skills that possessed by students was 66 . Based on the score criteria interpretation by Arikunto, it is categorized as good. The skill of conducting experiments is one of the skills of an integrated science process [13]. The skill of conducting experiments is defined as the activity of testing hypotheses by manipulating or controlling the independent variables and seeing the influence that occurs on the dependent variable [4].

This is likely due to the learning methods given to participants currently referring to the 2013 curriculum which requires practicum activities to be carried out on a number of basic competencies [18]. The 2013 curriculum also applies a student-centered learning process (student center), it means that students are trained to be able to find and build understanding of their own concepts, as well as practical activities that train students to be able to formulate and solve problems independently. Based on the results of previous studies, it is known that learning methods can influence the development of integrated science process skills. Traditional learning methods (teacher center) cannot develop integrated science process skills in students [19]. It is also known that practicum is one form of activity that makes students learn actively to reconstruct their conceptual understanding [20].
In addition, practicum activities have a very important role in achieving science education goals, one of which is that they can develop basic skills in conducting experiments $[7,21,22]$. Whilst the types of science process skills that tend to be lower were owned by students, they were measuring and communicating skills. Measuring and communicating skills are part of basic science process skills. Measuring skill is the ability to interpret the number of objects quantitatively. Skills in measuring require knowledge to use equipment appropriately to carry out the calculations needed [23,24]. This skill is usually applied to students when using preparations and reading measurements [25]. The ability of students who tend to be low in measuring possibilities is due to lack of learning that involves the measurement process. Sometimes when doing an experiment, the students were accustomed to use materials that were ready to use, because the teacher or lab assistant have measured or prepared how many materials that will be used.

The way that can be used to improve the measuring skill of students is applying the inquiry learning methods, which states that the method of inquiry has a positive effect on measuring skills in students [26]. Through inquiry learning methods, students will be able to solve problems that occur in learning by doing and finding their own knowledge, and to prove their own knowledge directly. The development of good measurement skills is very effective in making quantitative observations, grouping, and comparing everything around, and communicating it to others [27].

Communication skills are the ability to use words, graphics, or symbols in describing an object or event [4]. The ability of students tends to be low in communicating the possibility because in the learning process students are not accustomed to explaining the material through pictures, graphs or tables [28]. Communication skills are the skills in choosing and using sentences, so that the information, ideas or the communication can be easily accepted by the interlocutor [29]. Communication skills are actually not only done verbally, but can also be done in written form. Communication skills possessed by students can help students in transferring, presenting knowledge in order to be able to extract information accurately.

The way to improve communication skills with students is to provide concrete examples during the learning process [30]. Learners will easily understand a complex and abstract concept if during the learning process takes place accompanied by real examples.

\section{Conclusions and Suggestions}

Based on the results of research on science process skills in high school students in the city of Cilegon, Banten, it is known that the average value of science process skills of students is still in the sufficient category, namely 58 . Experimental skills are the highest skills while the skills in 
measuring and communicating are the lowest skills possessed by students. Though science process skill is one of the important skills possessed by students in conducting the learning process, if students have good science process skills, students will be able to more easily understand learning concepts. Therefore, efforts are needed to improve science process skills in students, such as by applying learning methods that can improve science process skills, for example by using inquiry learning methods.

\section{REFERENCES}

[1] National Education Department. Competency Based Curriculum for Biology Subjects for Senior High Schools. Balitbang Puskurbuk Depdiknas, Jakarta, 2001.

[2] Handayani, G., Adisyahputra, Indrayanti, R. The relationship between integrated science process skills and ability to read comprehension of science literacy in prospective biology teacher students. Biosfer: Journal of Biological Education, Vol. 11 No.1, 21-31, 2018.

[3] Agustina, P., dan Saputra, A. Analysis of basic science process skills (KPS) of prospective biology teacher students in plant anatomy courses (Case study of Biology Education Study Program FKIP UMS 2015/2016 school year). Proceedings of the National Science Education Seminar (SNPS), 2016.

[4] Chiappetta, E., \& Koballa, T. Science Instruction in the Middle and Secondary Schools (5th ed), Merrill Prentice Hall, Upper Saddle River, NJ, 2002.

[5] Ongowo, R. O., \& Indoshi, F. C. Science process skills in the Kenya certificate of secondary education biology practical examinations. Creative Education, Vol.11, No.4, 713-717, 2013.

[6] Prasasti, P. A. T. The effectiveness of the scientific approach with guided experiments in science learning to empower the science process skills of elementary school students. Basic Education Profession, Vol.1, No.1, 19-26, 2017.

[7] Lestari, P., Ristanto, R., \& Miarsyah, M. Analysis of Conceptual Understanding of Botany and Metacognitive Skill in Pre-Service Biology Teacher in Jakarta, Indonesia. Journal for the Education of Gifted Young Scientists, 7(2), 199-214. 2019. https://doi.org/10.17478/jegys.515978

[8] Aydoğdu, B., et.al. The investigation of science process skills of elementary school teachers in terms of some variables: perspectives from turkey. Asia-Pacific Forum On Science Learning And Teaching, Vol.1, No.5, 2014.

[9] Kazeni, M.M.M. Development and validation of a test integrated science process skills for the further Education and training learners. Unpublished Master Thesis, University of Pretoria South Africa, 2005.

[10] Rillero, P. Process skills and content knowledge. Science Activities, Vol.3, No.35, 3-4, 1998.
[11] Arikunto, Suharsimi. Dasar-dasar Evaluasi Pendidikan. Bumi Aksara, Jakarta, 2012.

[12] Suderajat, Hari. Implementation of competency-based curriculum (KBK). CV. Cipta Cekas Grafika, Bandung, 2004.

[13] Dimyati \& Mudjiono. Study and Learning. Educational Development and Quality Improvement Project, Dirjen Dikti Depdikbud, Jakarta, 2004.

[14] Bahtiar, \& Dukomalamo, N. Basic science process skills of biology laboratory: improving through discovery learning Biosfer: Jurnal Pendidikan Biologi, Vol. 12, No. 1, 83-93, 2019.

[15] Supriyatin, Rahayu, S., Ristanto, R.H., Ichsan, I.Z. Improving hots in biology learning: A supplement book of plant growth and development. Universal Journal of Educational Research, 7(12), 2642-2646. 2019.

[16] Indriani, D. and Mercuriani, I. S. Experiential learning model with mind mapping on fungi: how to improve science process skills?. Biosfer: Jurnal Pendidikan Biologi, Vol.12, No. 2, 223-237, 2019.

[17] Baxter, L. M., \& Kurtz, M. J. When a Hypothesis is NOT an Educated Guess. Science \& Children Journal, Vol.38, No.7, 18-20, 2001.

[18] Ministry of Education and Culture. Guidelines for Assistance Activities Implementation of the 2013 Curriculum for School Supervisors, Principals, and Core Teachers. Pusbang Tendik Kemdikbud, Jakarta, 2013.

[19] Zeidan, Afif Hafez and Majdi Rashed Jayosi. (2015), Science Process Skills and Attitudes toward Science among Palestinian Secondary School Students. Journal of Education, Vol.1, No.1, 2015.

[20] Duda, H. J. Pembelajaran berbasis praktikum dan asesmennya pada sistem ekskresi untuk meningkatkan kemampuan berpikir kritis siswa kelas xi. VOX Edukasi, Vol.2, No.1, 29-39, 2010.

[21] Baeti, Nur Shinta, et.al. Pembelajaran berbasis praktikum bervisi sets untuk meningkatkan keterampilan laboratorium dan penguasaan kompetensi. Jurnal Inovasi Pendidikan Kimia, Vol.1, No.8, 1260-1270, 2014.

[22] Hofstein. The laboratory in chemistry education: thirty years of experience with developments, implementation, and research. Journal Research and Practice, Vol.3, No.5, 247-264, 2004.

[23] Abruscato, J. Teaching Children Science: A Discovery Approach. Prentice Hall, New Jersey, 1995.

[24] Carin, A. A., Bass, J. E., \& Contant, T. L. (2005). Methods for Teaching Science as Inquiry. Pearson Education, Inc. Upper Saddle River, NJ, 2005.

[25] Rauf, R. A., et.al. Inculcation of science process skills in a science classroom. Asian Social Science, Vol.8, No.9, 47-57, 2013.

[26] Miarsyah, M., Ristanto, R.H., Nurhayati, Mufida, S.N., Suparini, Zharroh, A.E. Development of adobe flash media integrated into hots on circulation system (af-hots bicycle media). International Journal of Advanced Trends in Computer Science and Engineering, 9(1), 896-903. 2020. 
https://doi.org/10.30534/ijatcse/2020/128912020

[27] Bundu, Patta. Penilaian Keterampilan Proses dan Sikap Ilmiah dalam Pembelajaran Sains SD. Depdiknas Dirjen Dikti, Jakarta, 2006.

[28] Elvanisi, et.al. Analisis keterampilan proses sains siswa sekolah menengah atas. Jurnal Inovasi Pendidikan IPA, Vol.2, No.4, 245-252, 2018.

[29] Yusefni, W., \& Sriyati, S. (2016). Pembelajaran IPA terpadu menggunakan pendekatan science writing heuristic untuk meningkatkan kemampuan komunikasi tulisan siswa SMP. Edusains, Vol.1, No.8, 9-17, 2016.

[30] Ambarsari, W., et.al. Penerapan pembelajaran inkuiri terbimbing terhadap keterampilan proses sains dasar pada pelajaran biologi siswa kelas VIII SMP Negeri 7 Surakarta. Jurnal Pendidikan Biologi, Vol. 1, No.5, 81-95, 2013. 